\title{
GEOCHEMICAL STUDY OF THE URBAN AND SUBURBAN AREA OF NAFPLION CITY, ARGOLIDHA PREFECTURE, HELLAS
}

\author{
Tassiou, . $^{1}$, and Vassiliades, E. ${ }^{1}$ \\ IInstitute of Geology and Mineral Exploration, 1 Spirou Louis Street, Olympic Village, Entrance C, 13677 \\ Acharnae,Attiki,Hellas, stassiou@igme.gr,evassiliades@igme.gr
}

\begin{abstract}
Soil, as the primary receptor of anthropogenic urban contamination acts as a sink for a variety of toxic and other hazardous substances. It constitutes, therefore, an indicator of contamination and may be utilised geochemically to assess environmental quality of urban and suburban areas.

In Nafplion, an urban and suburban area of $50 \mathrm{~km}^{2}$, was investigated using for the first time in Hellas an integrated approach with all available geoscientific techniques to make an in-depth environmental impact assessment. One of these techniques was applied geochemistry, which mapped the geochemistry of surface soil $(0-10 \mathrm{~cm})$ with 144 samples, collected on a regular grid of $500 \times 500 \mathrm{~km}$. The following fifty determinands were measured on the soil samples: $\mathrm{Ag}, \mathrm{Al}, \mathrm{As}, \mathrm{B}, \mathrm{Ba}, \mathrm{Be}, \mathrm{Bi}, \mathrm{Ca}$, $\mathrm{Cd}, \mathrm{Ce}, \mathrm{Co}, \mathrm{Cr}, \mathrm{Cu}, \mathrm{Fe}, \mathrm{Ga}, \mathrm{Ge}, \mathrm{Hg}, \mathrm{K}, \mathrm{La}, \mathrm{Li}, \mathrm{Mg}, \mathrm{Mn}, \mathrm{Mo}, \mathrm{Na}, \mathrm{Nb}, \mathrm{Ni}, \mathrm{P}, \mathrm{Pb}, \mathrm{Rb}, \mathrm{Re}, \mathrm{S}, \mathrm{Sb}, \mathrm{Sc}, \mathrm{Se}$, $\mathrm{Sn}, \mathrm{Sr}, \mathrm{Ta}, \mathrm{Te}, \mathrm{Th}, \mathrm{Ti}, \mathrm{Tl}, \mathrm{U}, \mathrm{V}, \mathrm{W}, \mathrm{Y}, \mathrm{Zn}, \mathrm{Zr}, \mathrm{pH}$, electrical conductivity and grain-size distribution.

The aim of the geochemical study was to distinguish, as far as possible, the origin of chemical elements, and (i) to classify them as geogenic or anthropogenic; (ii) to delineate contaminated areas, and (iii) to assess potential future impacts of human activities on soil.

Interpretation of the resulting geochemical patterns has shown that those of $\mathrm{Al}, \mathrm{Fe}, \mathrm{Be}, \mathrm{Ce}, \mathrm{Cr}, \mathrm{Co}$, $\mathrm{Ga}, \mathrm{Ge}, \mathrm{K}, \mathrm{La}, \mathrm{Li}, \mathrm{Mg}, \mathrm{Nb}, \mathrm{Ni}, \mathrm{Rb}, \mathrm{Sc}, \mathrm{Sr}, \mathrm{Tl}, \mathrm{V}, \mathrm{Y}, \mathrm{W}$ and $\mathrm{Zr}$ are of geogenic origin, since they are directly related to parent rocks, whereas patterns of $\mathrm{As}, \mathrm{B}, \mathrm{Ba}, \mathrm{Bi}, \mathrm{Ca}, \mathrm{Cd}, \mathrm{Cu}, \mathrm{Mn}, \mathrm{Mo}, \mathrm{Na}, \mathrm{P}, \mathrm{Pb}$, $S, S b, S n, T h, U$ and $Z n$ are interpreted as being of dual origin, geogenic and anthropogenic. In this paper, the geochemical distribution of only five elements shall be described, i.e., $\mathrm{Pb}, \mathrm{Zn}, \mathrm{Cu}, \mathrm{Ni}$ and $\mathrm{Na}$. This case study was indeed very interesting, since for the interpretation of some patterns, even the military history of the area had to be unravelled.
\end{abstract}

Key words: soil, urban geochemistry, Nafplion, Hellas.

\section{Introduction}

As more population is moving to towns, seeking better working and living conditions, there is a greater pressure on finding suitable land for industrial, residential and recreational use. Urban and suburban soil, because of past and current polluting activities, is considered to be of potentially high health risk with respect to toxic elements and organic compounds. Surface soil is the main receptor of urban contaminating activities, since it acts as a collector and a reservoir of toxic elements and other substances. It is, therefore, a good indicator of anthropogenic contamination, thus, allowing the geochemical assessment of the quality of the urban and suburban environment. Since, the qual- 


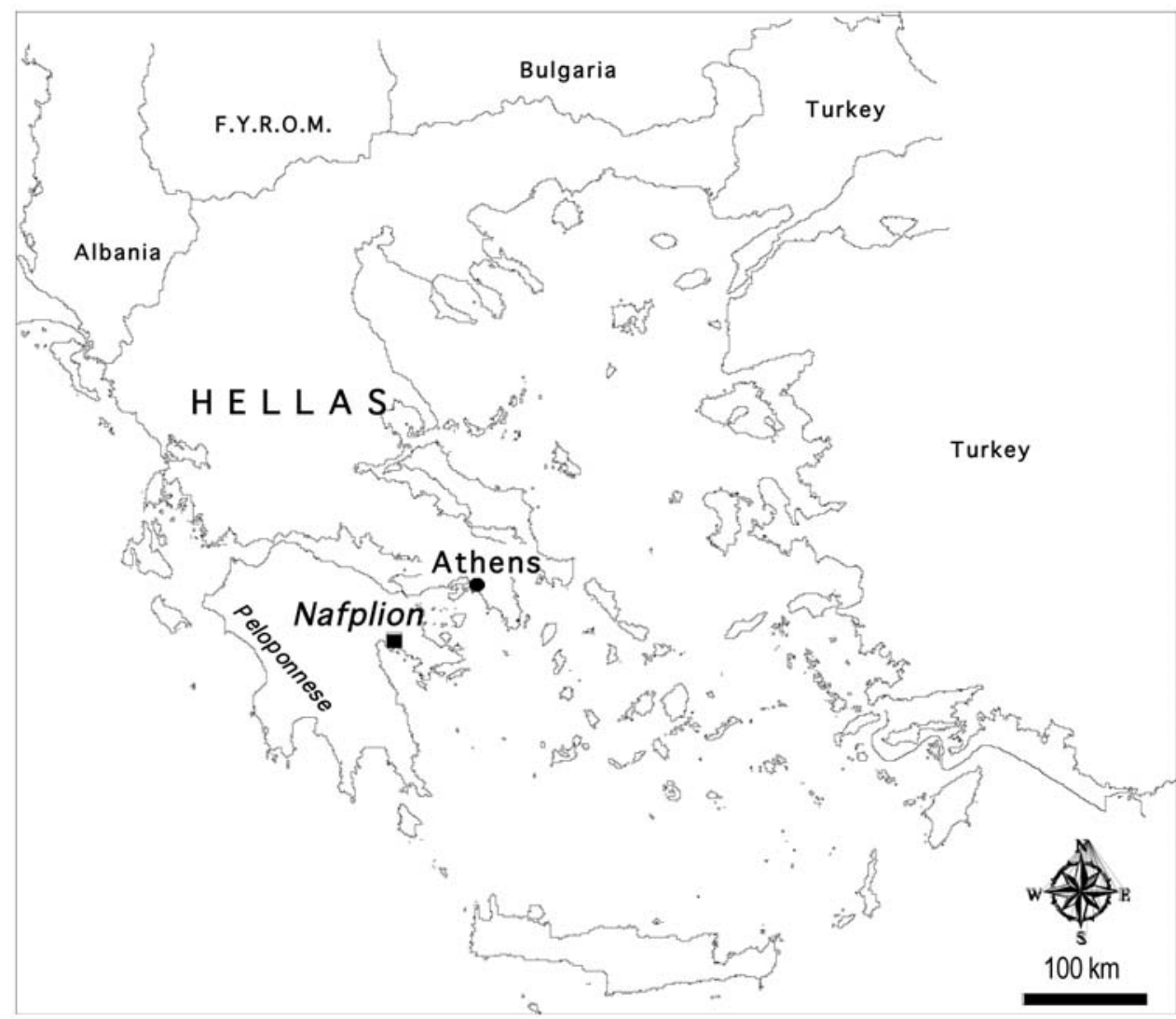

Fig. 1: Map of Hellas showing the location of the city of Nafplion in relation to Athens.

ity of our living environment affects our health and overall well being, it is necessary to map the distribution of toxic elements and other substances in soil, and to locate and delineate precisely hazardous areas, which must be rehabilitated before their reuse for residential, recreational, or even industrial, purposes.

The present work is part of an integrated geo-environmental study and refers to the results of the geochemical survey carried out in the urban-suburban area of the city of Nafplion (Tassiou, 2009; Vassiliades, 2009), which is situated in the north-eastern part of Peloponnese, Hellas (Fig. 1). The integrated geo-environmental study covers an area of $50 \mathrm{~km}^{2}$, and is delimited to the south by the Palamidi hill, to the east by Aria hill and the Exostis-Lefkakia depression, to the north by the ArgosTirintha-Nafplion plain and to the west by the Akronafplia (Arvanitia) peninsula (Fig. 2).

\section{Objectives of urban geochemical survey}

The aims of the soil geochemical study, carried out in the urban-suburban area of the city of Nafplion, were to distinguish, as far as possible, the origin of inorganic chemical elements, and (i) to classify them as geogenic or anthropogenic; (ii) to delineate contaminated areas, and (iii) to assess potential future impacts of human activities on surface soil. 


\section{Lithology and morphology}

In summary, the geological formations on which the residual soil was developed are the following (Photiades, 2008, 2010):

- neritic limestone of Lower to Upper Cretaceous age with its base rich in serpentinite breccioconglomerate;

- limestone and dolomite of Upper Triassic to Lower Jurassic age, locally with Fe-Mn encrustrations;

- serpentinite tectonic mélange;

- flysch mélange;

- tectono-sedimentary mélange (clastic ophiolithic formation),

- Quaternary alluvial deposits with swampy and brackish soil, and

- Recent fluvial deposits comprising heterogeneous coarse materials, derived from the erosion of the pre-Neogene basement.

Morphologically, the area constitutes an old weathered surface. The limestone outcrops are strongly weathered, and the collected soil samples are mostly residual (terra rossa).

\section{Methods}

\subsection{Sampling and sample preparation}

The routine soil samples $(0-10 \mathrm{~cm})$ were collected from a regular grid of $500 \times 500 \mathrm{~m}$ that covered an area of $50 \mathrm{~km}^{2}$. Duplicate field samples were collected from $10 \%$ of the sites for quality control purposes, and the estimation of sampling, analytical and geochemical variance. In total, 144 soil samples were collected, weighing about one kilogram each. The soil samples were dried at $30^{\circ} \mathrm{C}$ and then sieved through a $<2$ mm nylon screen.

\subsection{Chemical analysis}

The following chemical elements were determined by an ICP-AES Spectrometer after a hot aqua regia leach: Ag, Al, As, B, Ba, Be, Bi, Ca, Cd, Ce, Co, Cr, Cu, Fe, Ga, Ge, Hg, K, La, Li, Mg, Mn, Mo, Na, Nb, Ni, P, Pb, Rb, Re, S, Sb, Sc, Se, Sn, Sr, Ta, Te, Th, Ti, Tl, U, V, W, Y, Zn and Zr. Aqua regia dissolution is effective for base metals and associated elements in sulphides, oxides and carbonates. Rock forming elements and refractories are only partially attacked. It is noted that the aqua regia leach is partial for $\mathrm{B}, \mathrm{Ba}, \mathrm{Be}, \mathrm{Ca}, \mathrm{Ce}, \mathrm{Cr}, \mathrm{Fe}, \mathrm{Ga}, \mathrm{Ge}, \mathrm{La}, \mathrm{Li}, \mathrm{Mg}, \mathrm{Nb}, \mathrm{Rb}, \mathrm{Re}, \mathrm{Sb}, \mathrm{Sc}, \mathrm{Sn}$, $\mathrm{Sr}$, Ta, Te, Th, Ti, Tl, W and Zr, and limited for Al, K and $\mathrm{Na}$. In addition, the soil $\mathrm{pH}$, conductivity and the grain-size distribution were also determined.

The quality of analytical results was monitored by laboratory internal control samples, blanks and subsamples of the routine soil and field duplicates. Overall analytical precision was better than 5\% at the $95 \%$ confidence level for almost all elements determined.

\subsection{Data processing}

A geostatistical spatial structural analysis study was performed on the geochemical data of each element by plotting semi-variograms in different directions, and testing the extracted parameters by point kriging before plotting its distribution map by ordinary kriging with Golden Software's Surfer program (Tassiou, 2009; Vassiliades, 2009). A ten grade colour scale was used for map plotting, which is based on the following percentiles: $2.5,5,10,15,25,50,75,90,95$ and 97.5. 


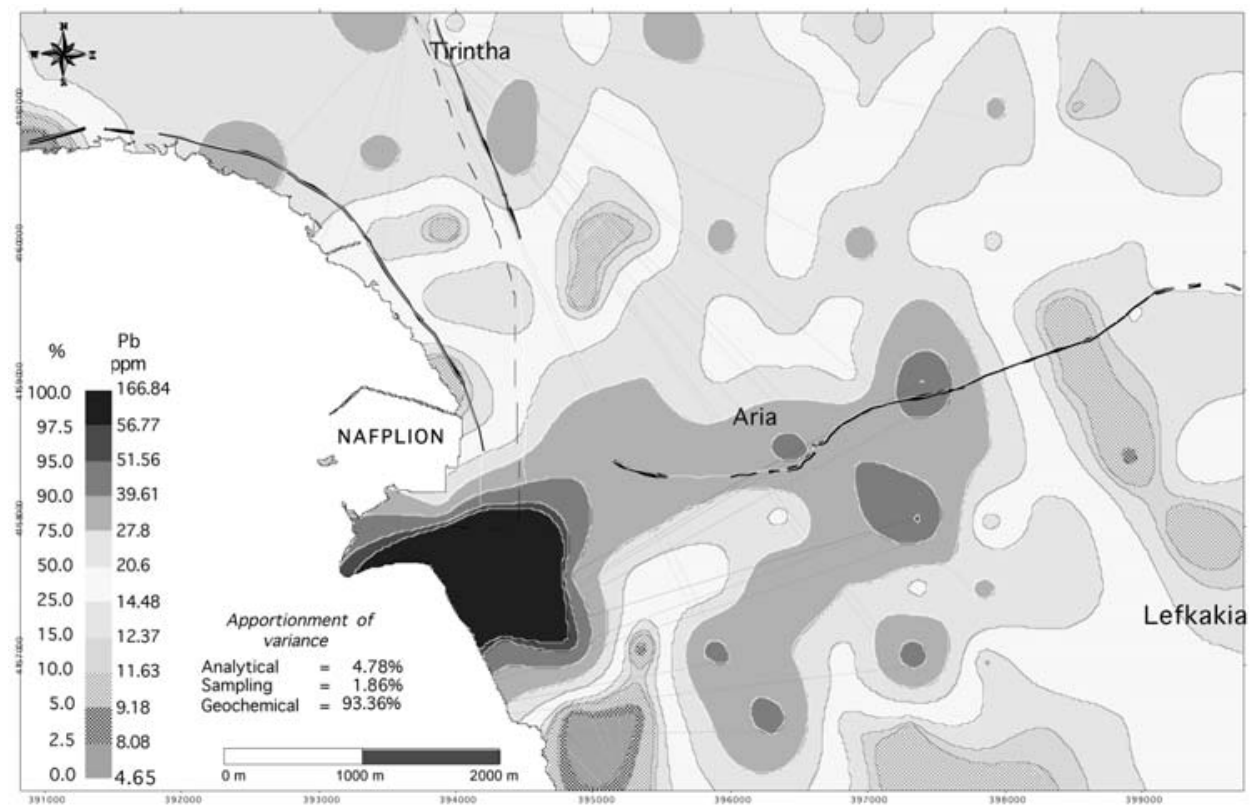

Fig. 2: Geochemical distribution of aqua regia extractable $\mathrm{Pb}$ in the $<2 \mathrm{~mm}$ fraction of soil $(0-10 \mathrm{~cm})$, Nafplion, Peloponnese, Hellas.

\section{Results}

In this paper, the geochemical distribution of only a few elements is described, e.g., $\mathrm{Pb}, \mathrm{Sn}, \mathrm{Cu}, \mathrm{Ni}$, and Na. For a full description of results the reports by Tassiou (2009) and Vassiliades (2009) should be consulted.

\subsection{Lead $(\mathrm{Pb})$ distribution}

Lead varies in surface soil $(0-10 \mathrm{~cm})$ from 4.65 to $166.8 \mathrm{ppm}$, with a mean and median of 30.0 and $20.6 \mathrm{ppm}$, respectively (Fig. 2). One sample had a value of $882 \mathrm{ppm} \mathrm{Pb}$, and was removed for the data processing, because it distorted the patterns. Levels of $\mathrm{Pb}>51.56$ ppm characterise the city of Nafplion, and especially the area of Palamidio castle, with the source of polluting activities going back to the Hellenic war of independence against Turkey in the early nineteenth century. Elevated $\mathrm{Pb}$ values are also observed near to major roads.

\subsection{Tin (Sn) distribution}

The $\mathrm{Sn}$ variation in surface soil $(0-10 \mathrm{~cm})$ is from 0.1 to $17.6 \mathrm{ppm}$, with a mean and median of 1.69 and $0.97 \mathrm{ppm}$, respectively (Fig. 3). Given that $11 \mathrm{ppm} \mathrm{Sn}$ is the maximum total value for uncontaminated soil (Chapman, 1972; Kabata-Pendias and Pendias 1984), values >9 ppm Sn, specifically in the city of Nafplion, and around Palamidi hill, appear to be related to anthropogenic activities. Similar to $\mathrm{Pb}$, elevated $\mathrm{Sn}$ values are observed near to major roads. 


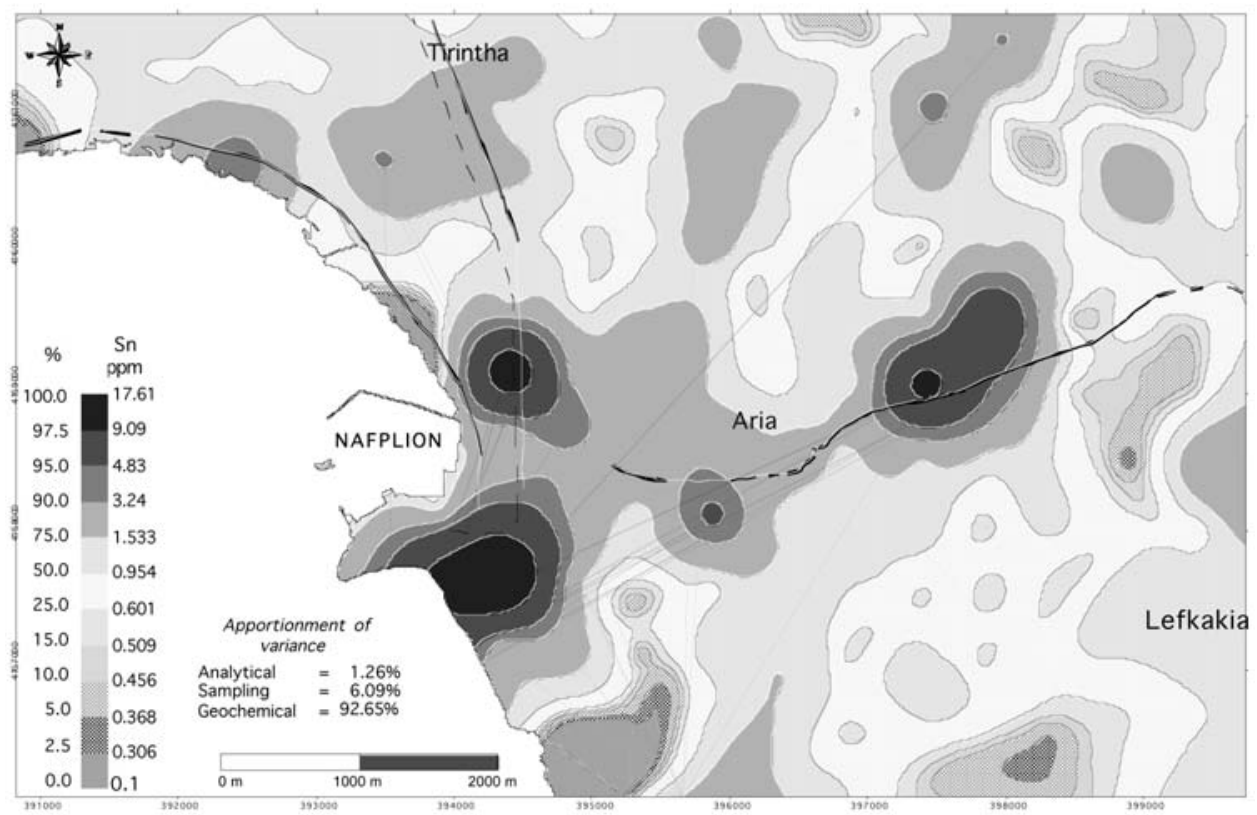

Fig. 3: Geochemical distribution of aqua regia extractable $\mathrm{Sn}$ in the $<2 \mathrm{~mm}$ fraction of soil $(0-10 \mathrm{~cm})$, Nafplion, Peloponnese, Hellas.

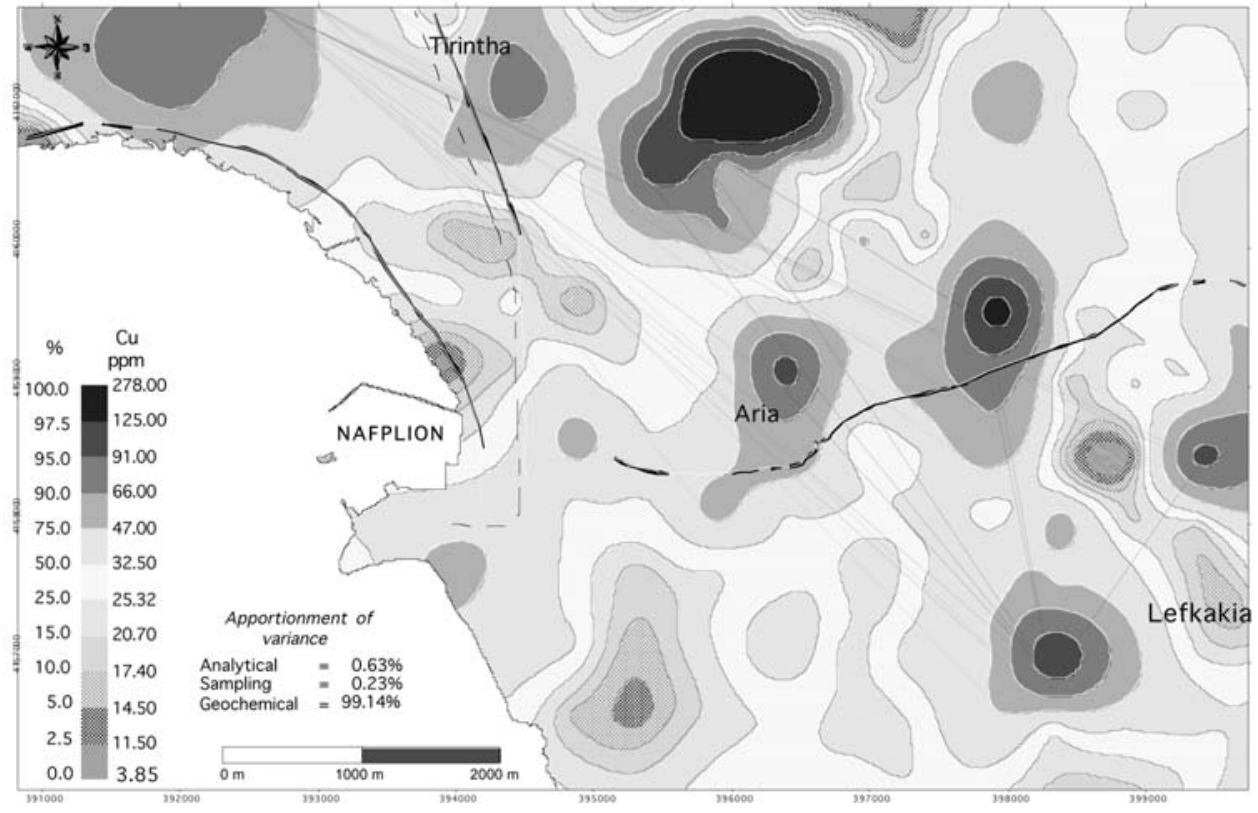

Fig. 4: Geochemical distribution of aqua regia extractable $\mathrm{Cu}$ in the $<2 \mathrm{~mm}$ fraction of soil $(0-10 \mathrm{~cm})$, Nafplion, Peloponnese, Hellas. 


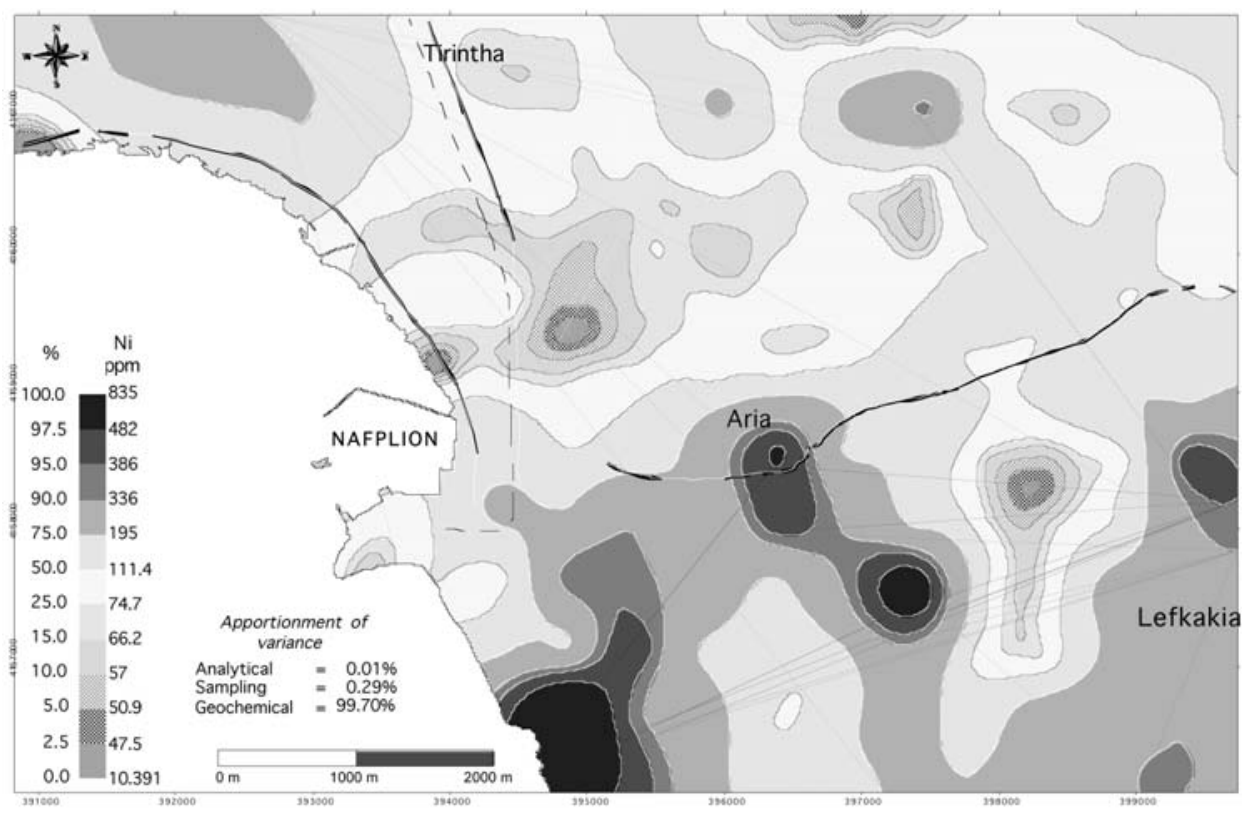

Fig. 5: Geochemical distribution of aqua regia extractable $\mathrm{Ni}$ in the $<2 \mathrm{~mm}$ fraction of soil $(0-10 \mathrm{~cm})$, Nafplion, Peloponnese, Hellas.

\subsection{Copper (Cu) distribution}

Copper varies in surface soil $(0-10 \mathrm{~cm})$ from 3.85 to $278 \mathrm{ppm}$, with a mean and median of 41.6 and $32.7 \mathrm{ppm}$, respectively (Fig. 4). The elevated $\mathrm{Cu}$ values ( $>47 \mathrm{ppm}$ ) in the north part of the study area, to the north-east of Aria and to the south-west of Lefkakia are considered to be due to agricultural activities, i.e., copper sulphate is used as a herbicide, fungicide and pesticide.

\subsection{Nickel (Ni) distribution}

The Ni distribution in surface soil $(0-10 \mathrm{~cm})$ varies from 10.4 to $835.6 \mathrm{ppm}$, with a mean and median of 158.3 and $112.0 \mathrm{ppm}$, respectively (Fig. 5). The high Ni values characterise the flysch tectonic mélange, which locally includes olistoliths of mafic lava, serpentinite and ophiolithic rocks, as well as the tectono-sedimentary mélange of Upper Jurassic and the serpentinite tectonic mélange. The geochemical patterns of $\mathrm{Ni}$ are almost identical to those of $\mathrm{Cr}$ and partly of $\mathrm{Co}$, suggesting, therefore, that the anomalous patterns are of geogenic origin.

\subsection{Sodium $(\mathrm{Na})$ distribution}

Sodium varies in surface soil $(0-10 \mathrm{~cm})$ from 0.005 to $0.864 \%$, with a mean and median of 0.033 and $0.015 \%$, respectively (Fig. 5). High Na concentrations are observed in the western part of the area along the coast, and mainly to the north of Nafplion. The reasons for these elevated Na values is surface soil are probably sea spray, and irrigation with saline water due to marine water intrusion caused by over pumping of shallow aquifers. This area is also characterised by high values of $\mathrm{B}, \mathrm{S}$ and $\mathrm{Sr}$, supporting, therefore, the marine influence interpretation. 


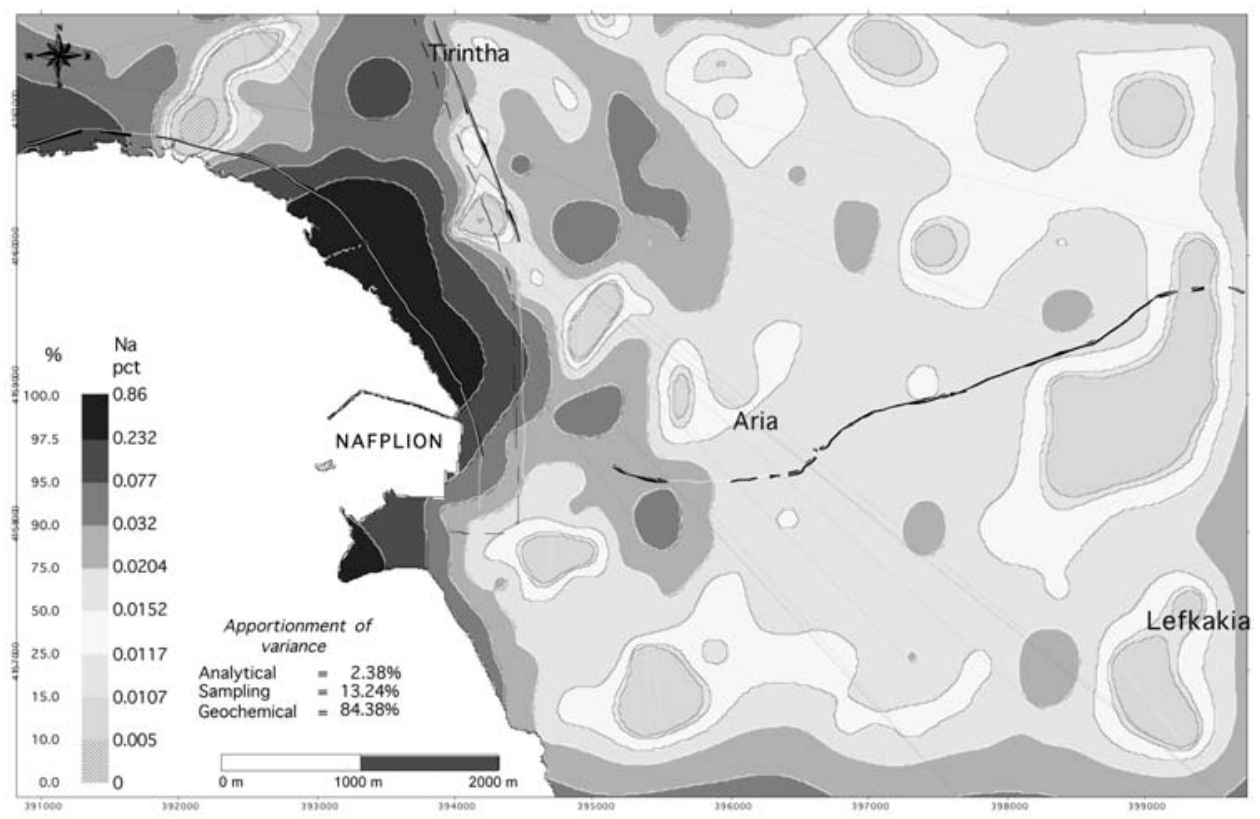

Fig. 6: Geochemical distribution of aqua regia extractable $\mathrm{Na}$ in the $<2 \mathrm{~mm}$ fraction of soil $(0-10 \mathrm{~cm})$, Nafplion, Peloponnese, Hellas.

\section{Conclusions}

Interpretation of geochemical patterns of elements, presented on maps, is a complex, and difficult task, because it requires an integrated evaluation of all available information. It involves the study of raw data, their statistical parameters, including linear correlation coefficients, as well as $\mathrm{pH}$, electrical conductivity, particle size distribution, geology and geomorphology of the area, and finally insitu observations with respect to land use.

Elevated geochemical patterns of $\mathrm{Cr}, \mathrm{Ni}, \mathrm{Co}, \mathrm{Mg}$ and $\mathrm{pH}$ describe geological structures, such as the tectono-sedimentary mélange and serpentinite mélange. Areas with intense chemical weathering of limestone (occurrence of terra rossa) are indicated by elevated geochemical patterns of $\mathrm{Al}$ and low $\mathrm{Ca}$. In the terra rossa there is an accumulation of many elements (e.g., $\mathrm{Al}, \mathrm{As}, \mathrm{Ba}, \mathrm{Be}, \mathrm{Cd}, \mathrm{Ce}, \mathrm{La}$, $\mathrm{Ga}, \mathrm{Ge}, \mathrm{Fe}, \mathrm{Mn}, \mathrm{Pb}, \mathrm{Sb}, \mathrm{Sc}, \mathrm{V}, \mathrm{Zn}$ ), and the resulting patterns are considered to be of geogenic origin. Other elements with values, exceeding the natural geochemical background, such as $\mathrm{Pb}, \mathrm{Sn}, \mathrm{Sb}$, $\mathrm{Zn}, \mathrm{Mo}, \pm \mathrm{As}, \pm \mathrm{Bi}$, are associated with urban development. Whereas, locally elevated values of $\mathrm{Cu}$, $\mathrm{P}, \mathrm{U}, \mathrm{Zn}, \pm \mathrm{Cd}$ and \pm Th occur in agricultural areas, and are ascribed, therefore, to be caused mainly by anthropogenic activities (Tassiou, 2009).

It is concluded that overall, the distribution patterns of chemical elements in the Nafplion urban and suburban area are mainly of geogenic origin, and that anthropogenic contamination is of local significance.

Finally, urban geochemical studies are important, because they provide fundamental data about the chemical state of our living and working environment, and they also establish the geochemical baseline against which comparisons can be made in the future by either monitoring programmes or accidents of any type. 


\section{Acknowledgments}

This paper is published by permission of the I.G.M.E. General Director. The project "Collection and Documentation of Geothematic Information of Urban and Suburban areas of Hellas - Pilot Applications" (Subproject 3: "Integrated geological, engineering geological, hydrogeological, geochemical and geophysical study of the urban and suburban pilot area of Nafplion, Argolidha Prefecture") was co-financed by the third EU Community Support Framework Programme and the Hellenic State (2000-2006), Operational programme "Competitiveness", Priority Axis 7 "Energy and Sustainable Development", Measure 7.3 "Exploitation of natural resources and support in meeting environmental commitments". The Director of the I.G.M.E. Division of Geochemistry and Environment, EurGeol Alecos Demetriades, is thanked for his support and constructive comments for the improvement of this concise paper.

\section{References}

Chapman, H.D. (Editor), 1972. Diagnostic criteria for plants and soils. University of California, Riverside, California, 793 pp.

Kabata Pendias, A. \& Pendias, H., 1984. Trace elements in soils and plants. CRC Press, Inc., Boca Raton, Florida, 315 pp.

Photiades, A., 2008. Geological study of the urban and suburban pilot area of Nafplion (Argolidha Prefecture). Report of Subproject 6920/003: Integrated geological, engineering geological, hydrogeological, geochemical and geophysical study of the urban and suburban pilot area of Nafplion Argolidha. Institute of Geology and Mineral Exploration, Athens, Hellas, 15 pp. (text in Greek).

Photiades, A., 2010. Geological survey at a scale of 1:5000 of the greater Nafplion area (NW Argolis, Greece). This volume.

Tassiou, S., 2009. Geochemical environmental study of the urban-suburban area of Nafplion, Volume 2: Interpretation text. Report of Subproject 6920/003: Integrated geological, engineering geological, hydrogeological, geochemical and geophysical study of the urban and suburban pilot area of Nafplion Argolidha. Institute of Geology and Mineral Exploration, Acharnae, Attiki, Hellas, 132 pp. (text in Greek).

Vassiliades, E., 2009. Geochemical environmental study of the urban-suburban area of Nafplion, Volume 2: Geochemical maps. Report of Subproject 6920/003: Integrated geological, engineering geological, hydrogeological, geochemical and geophysical study of the urban and suburban pilot area of Nafplion Argolidha. Institute of Geology and Mineral Exploration, Acharnae, Attiki, Hellas, 48 pp. (text in Greek). 